\title{
Bacterial Outer Membrane Vesicles Provide Broad-Spectrum Protection against Influenza Virus Infection via Recruitment and Activation of Macrophages
}

\author{
Eun-Hye Bae ${ }^{a}$ Sang Hwan Seo ${ }^{a}$ Chang-Ung Kim ${ }^{a}$ b Min Seong Jang ${ }^{a}$ \\ Min-Suk Song ${ }^{c}$ Tae-Young Lee ${ }^{a}$ Yu-Jin Jeong ${ }^{a}$ Moo-Seung Lee ${ }^{a, e}$ \\ Jong-Hwan Park ${ }^{d}$ Pureum Lee ${ }^{a, e}$ Young Sang Kim ${ }^{b}$ Sang-Hyun Kim ${ }^{f}$ \\ Doo-Jin Kim ${ }^{a}$, b, e
}

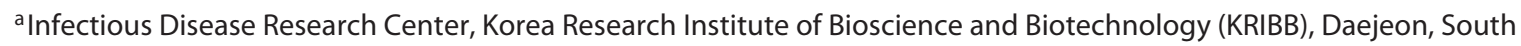
Korea; ${ }^{b}$ Department of Biochemistry, Chungnam National University, Daejeon, South Korea; ${ }^{C}$ College of Medicine and Medical Research Institute, Chungbuk National University, Cheongju, South Korea; ${ }^{\mathrm{d}}$ College of Veterinary Medicine, Chonnam National University, Gwangju, South Korea; ' University of Science and Technology (UST), Daejeon, South Korea; ${ }^{f}$ College of Veterinary Medicine, Gyeongsang National University, Jinju, South Korea
\end{abstract}

\section{Keywords}

Influenza - Outer membrane vesicle · Antiviral .

Macrophages · Type I interferon

\begin{abstract}
Influenza A virus (IAV) poses a constant worldwide threat to human health. Although conventional vaccines are available, their protective efficacy is type or strain specific, and their production is time-consuming. For the control of an influenza pandemic in particular, agents that are immediately effective against a wide range of virus variants should be developed. Although pretreatment of various Toll-like receptor (TLR) ligands have already been reported to be effective in the defense against subsequent IAV infection, the efficacy was limited to specific subtypes, and safety concerns were
\end{abstract}

Eun-Hye Bae and Sang Hwan Seo contributed equally to this work.

\section{KARGER}

E-Mail karger@karger.com www.karger.com/jin
(C) 2019 The Author(s) Published by S. Karger AG, Basel

Karger

Open access

This article is licensed under the Creative Commons AttributionNonCommercial-NoDerivatives 4.0 International License (CC BYNC-ND) (http://www.karger.com/Services/OpenAccessLicense). Usage and distribution for commercial purposes as well as any distribution of modified material requires written permission. also raised. In this study, we investigated the protective effect of an attenuated bacterial outer membrane vesicle harboring modified lipid A moiety of lipopolysaccharide (fmOMV) against IAV infection and the underlying mechanisms. Administration of fmOMV conferred significant protection against a lethal dose of pandemic H1N1, PR8, H5N2, and highly pathogenic $\mathrm{H} 5 \mathrm{~N} 1$ viruses; this broad antiviral activity was dependent on macrophages but independent of neutrophils. fmOMV induced recruitment and activation of macrophages and elicited type I IFNs. Intriguingly, fmOMV showed a more significant protective effect than other TLR ligands tested in previous reports, without exhibiting any adverse effect. These results show the potential of fmOMV as a prophylactic agent for the defense against influenza virus infection.

(C) 2019 The Author(s)

Published by S. Karger AG, Basel
Prof. Sang-Hyun Kim

College of Veterinary Medicine

Gyeongsang National University

501 Jinjudae-ro, Jinju 52828 (South Korea)

E-Mail vetmicro@gnu.ac.kr

Dr. Doo-Jin Kim

Infectious Disease Research Center

Korea Research Institute of Bioscience and Biotechnology (KRIBB)

125 Gwahak-ro, Daejeon 34141 (South Korea)

E-Mail golddj@kribb.re.kr 


\section{Introduction}

Currently available influenza vaccines have effectively reduced disease incidence; however, 3-5 million cases of severe illness, with 250,000-500,000 deaths, are reported annually, worldwide [1]. One of the reasons for high incidence is constant genomic changes in the virus, termed as antigenic drift or shift, which allows the virus to evade the antibody response generated by vaccination [2]. These genetic changes elicit new, highly pathogenic strains, which have the potential to cause a pandemic [3]. For these, new seasonal vaccines need to be formulated annually, which is a time-consuming process. Therefore, there is a need for the development of a broad-spectrum antiviral agent that is effective against a large variety of viral strains and elicits antiviral effect immediately.

Innate immunity can confer broad-spectrum and immediate defense against various pathogens including influenza virus. Innate immune responses are initiated mainly by recognition of pathogen-associated molecular patterns (PAMPs) in the pathogen via pattern recognition receptors such as Toll-like receptors (TLRs) [4-6], and TLR-stimulated innate immune cells protect the host against the pathogen's first attack as well as subsequent reinfections, which is termed "trained immunity" [7, 8]. Based on these findings, various PAMPs such as lipopolysaccharide (LPS), palmitoylated peptides, and the unmethylated CpG oligodeoxynucleotide have been utilized to induce anti-influenza innate immunity [9-14]. However, the effects achieved so far are insufficient to protect against infection by a wide spectrum of viral strains. For example, LPS protects the host against a lethal dose of PR8 virus, but the effect was significantly reduced in the SpHA/WSN virus infection model $[11,15]$, and the stimulation of TLR2 also required supplement of a TLR9 ligand for the significant protection [12]. Another study reported that stimulation of TLR3 by synthetic liposomal polyriboinosinic-polyribocytidylic acid resulted in moderate survival rates (70 and $63 \%$ after infection by PR8 and H5N1, respectively) [13]. These previous studies indicate the requirement for a sophisticated strategy or novel agent to achieve broad-spectrum anti-influenza efficacy involving activation of innate immunity.

Outer membrane vesicles (OMVs) are phospholipid bilayer vesicles produced naturally by Gram-negative bacteria. Since OMVs contain various bacterial antigens [16], they have been studied as a vaccine candidate against pathogenic bacteria such as Vibrio cholerae and Borrelia burgdorferi $[17,18]$. Notably, the OMV from Neisseria meningitidis was the first to be licensed for humans as a

OMV-Mediated Antiviral Effect via Macrophages vaccine component [19]. In addition to bacterial proteins, these vesicles also contain TLR ligands such as LPS, lipoproteins, and flagellin $[16,20]$, and in this regard, OMVs augmented adaptive immune response to the coadministered antigens via activation of innate immunity $[5,6]$. Previously, we generated fmOMV, which stands for further-modified OMV, of which lipid A is a dephosphorylated and underacylated species that resulted from both expression of the LpxF 4' -phosphatase and deletion of the $m s b B / p a g P$ lipid A myristoyl/palmitoyltransferase genes. This OMV showed a significant adjuvant effect on a seasonal influenza vaccine exhibiting much attenuated TLR4-stimulating activity in vitro and endotoxicity in vivo [21, 22]. Although the adjuvant effect of OMVs has been reported in various antigen models, the antiviral effects via activation of innate immunity have not yet been addressed.

In this study, we showed that fmOMV elicits host innate immune response against influenza virus infection. Intranasal administration of fmOMV resulted in the recruitment and activation of macrophages in the lung tissue, and these macrophages sufficiently protect infection from different influenza viruses; pH1N1, PR8, H5N2, and highly pathogenic $\mathrm{H} 5 \mathrm{~N} 1$. These findings suggest the potential of fmOMV as a novel antiviral agent against infection from broad-spectrum influenza viruses.

\section{Materials and Methods}

\section{Purification of $f m O M V$}

fmOMV was produced by transforming E. coli W3110 $\Delta m s b B /$ $\triangle p a g P$ mutant strain with pWSK29-LpxF plasmid as previously reported [23]. After removing the bacteria by centrifugation $(11,000 \mathrm{~g})$, the supernatant was filtered using a $0.22-\mu \mathrm{m}$ pore filter (Merck, NJ, USA). fmOMV in the filtrate were precipitated in 390 $\mathrm{g} / \mathrm{L}$ ammonium sulphate solution, and the collected pellets were centrifuged again at $16,000 \mathrm{~g}$ for $15 \mathrm{~min}$. The pellets were ultracentrifuged in a sucrose gradient solution for further purification.

Fig. 1. Modified outer membrane vesicle (fmOMV) stimulates diverse Toll-like receptors (TLRs). a Structure of lipid A moiety on fmOMV. b HEK293 cells expressing mouse TLR2, TLR4, TLR5, or TLR9 were cultured with indicated amounts of fmOMV or corresponding ligand (PAM3 $100 \mathrm{ng} / \mathrm{mL}$; LPS $100 \mathrm{ng} / \mathrm{mL}$; flagellin 100 $\mathrm{ng} / \mathrm{mL}$; or CPG $100 \mathrm{ng} / \mathrm{mL}$ ) for $24 \mathrm{~h}$. The extent of fmOMV- or TLR ligand-induced TLR stimulation was determined by measuring secreted embryonic alkaline phosphatase activity using QUANTI-Blue colorimetric enzyme assay. Data are presented as mean \pm standard deviation from triplicate culture wells, at optical density (OD) of $570 \mathrm{~nm}$. ${ }^{* * *} p<0.001,{ }^{* *} p<0.01$.

(For figure see next page.)

J Innate Immun 2019;11:316-329

317 

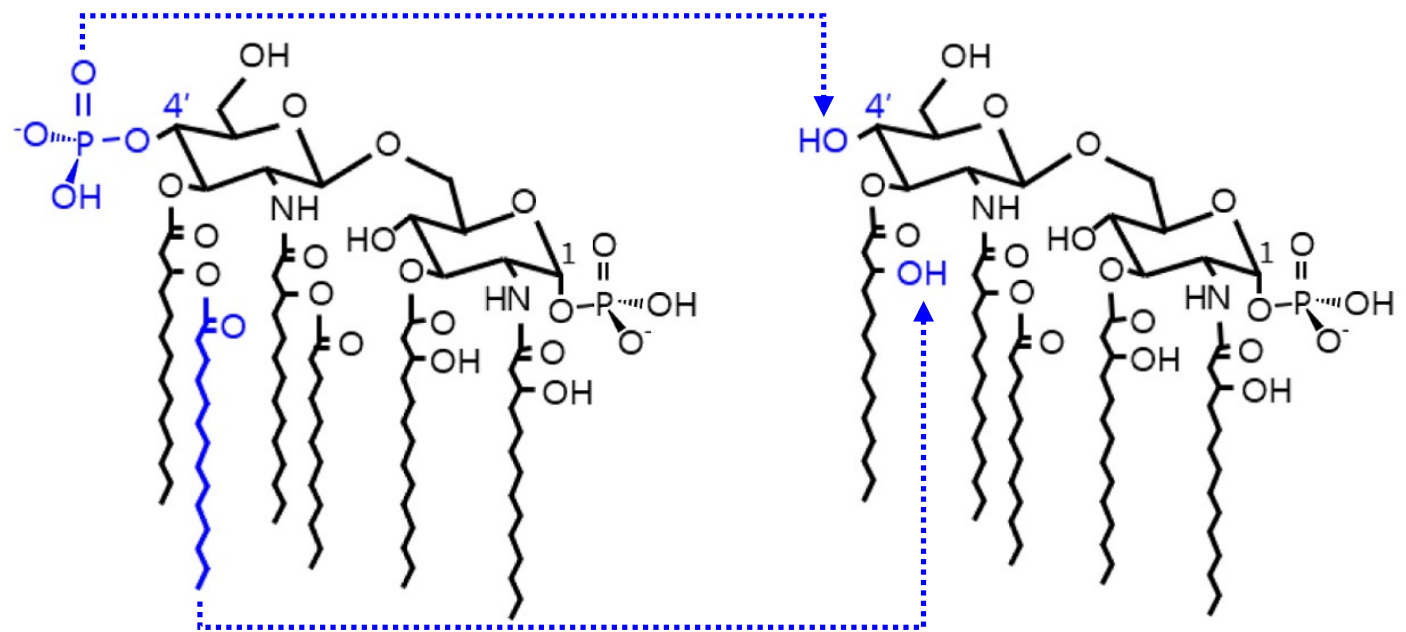

$\triangle m s b B / \triangle p a g P$ : Penta-acylated

a

$$
\text { Lipid A moiety on native OMV }
$$

Lipid A moiety on fmOMV
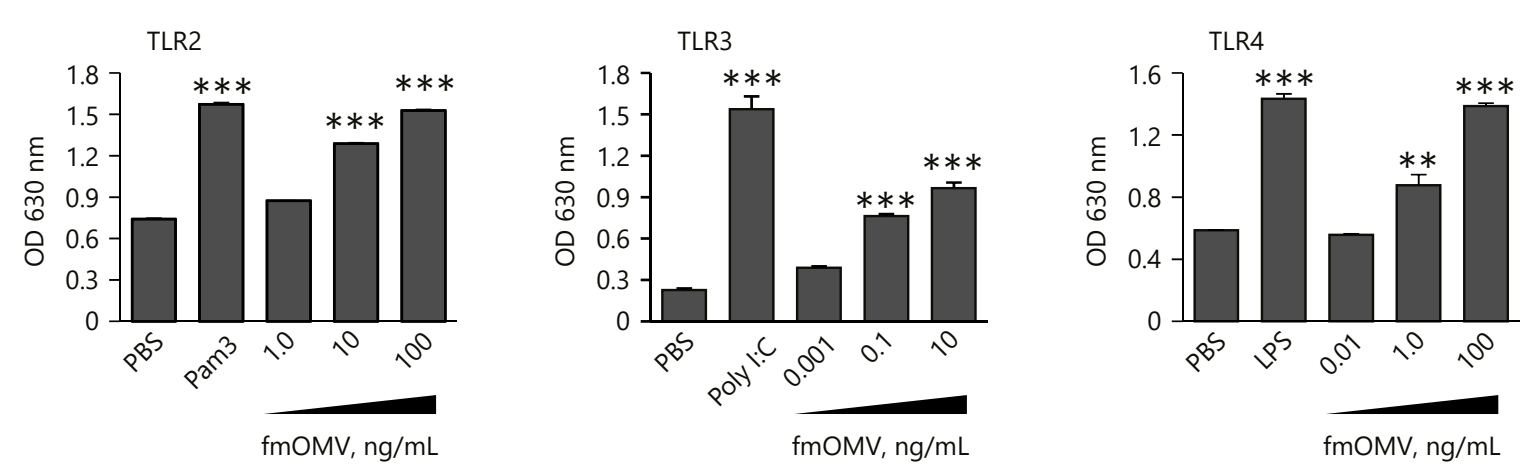

b
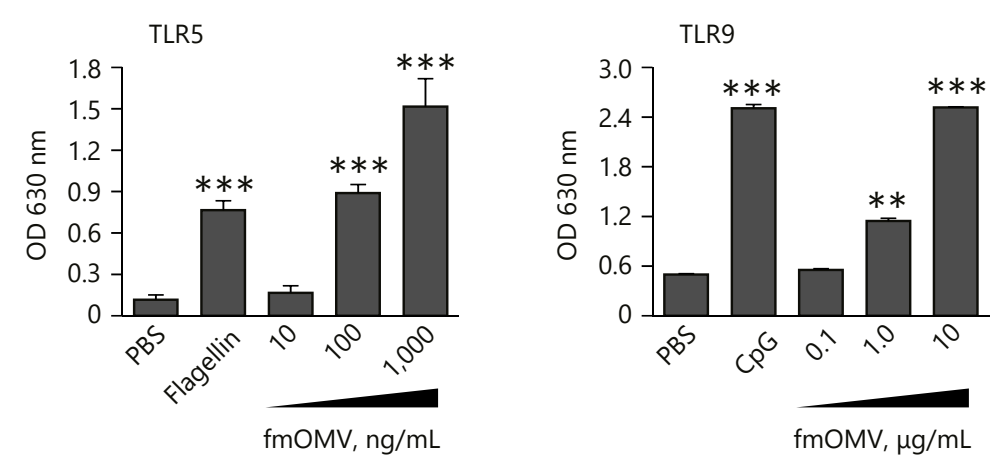


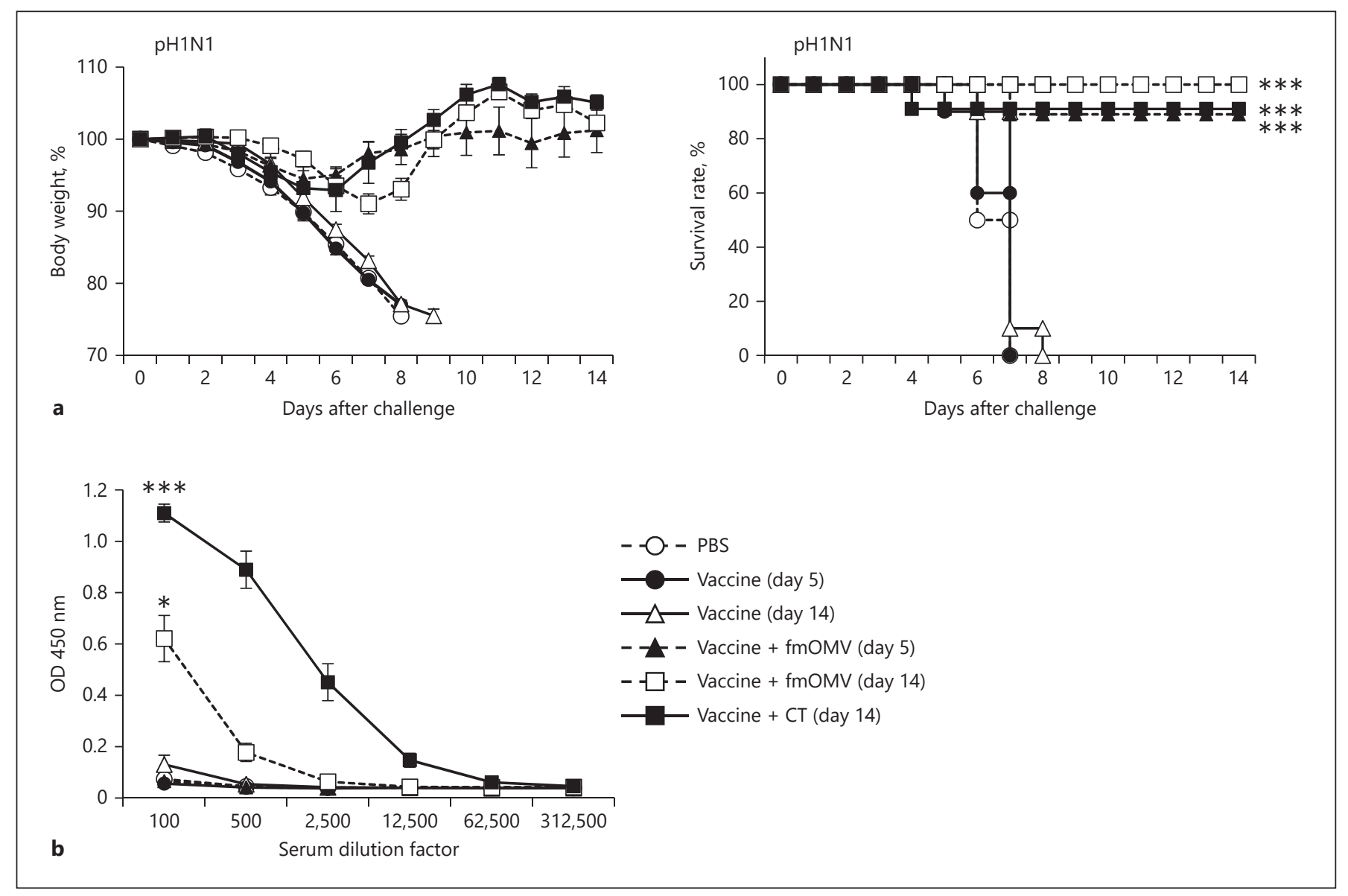

Fig. 2. Antiviral activity of fmOMV is independent of the adaptive immune response. Mice $(n=10)$ were intranasally immunized with the trivalent split influenza vaccine mixed with fmOMV or cholera toxin, and then challenged with $\mathrm{pH} 1 \mathrm{~N} 1$ virus at 5 and 14 days after the injection. a After challenge, the mice were monitored for changes in body weight and survival rate for 14 days. b Sera were collected before virus challenge, and the virus-specific antibody response was determined by ELISA. c-f Mice $(n=8)$ were injected with fmOMV alone. At 3, 7, or 14 days after the injection, the mice were infected with $\mathrm{pH} 1 \mathrm{~N} 1$ virus. The vaccinated group was immunized intramuscularly with $\mathrm{pH} 1 \mathrm{~N} 1$ split vaccine fol-

\section{TLR Signaling Assay}

HEK-Blue ${ }^{\mathrm{TM}}$ mTLR2, mTLR3, mTLR4, mTLR5, or mTLR9 (Invivogen, CA, USA) cell lines were maintained in RPMI1640 media (Life technologies, MA) supplemented with $10 \%$ fetal bovine serum (FBS; GE Healthcare, UK) and $1 \times$ antibiotics (Life Technologies). During activation, each cell line was resuspended in HEKBlue $^{\mathrm{TM}}$ Detection media (Life Technologies), seeded at $5 \times 10^{4}$ cells/well in 96-well plates, and treated with fmOMV or control reagents; Pam ${ }_{3}$ Cys-Ser-(Lys) ${ }_{4}$ (Pam3, $1.0 \mu \mathrm{g} / \mathrm{mL}$; Merck Millipore, Germany), poly I:C (10 $\mu \mathrm{g} / \mathrm{mL}), \mathrm{LPS}(100 \mathrm{ng} / \mathrm{mL})$, flagellin $(1.0 \mu \mathrm{g} /$ $\mathrm{mL}$ ), or CpG ODN 1826 (CpG, $1.0 \mu \mathrm{g} / \mathrm{mL}$ ) (Invivogen). After 24-h incubation, the secreted alkaline phosphatase activity was measured at $630 \mathrm{~nm}$.

OMV-Mediated Antiviral Effect via Macrophages lowed by a booster injection after 2 weeks $(n=8)$. Two weeks after the second injection, the mice were challenged with the $\mathrm{pH} 1 \mathrm{~N} 1$ virus. c The survival rates were monitored for 2 weeks after the $\mathrm{pH} 1 \mathrm{~N} 1$ viral challenge. $\mathbf{d}$ The lung tissues were collected at 7 days after the viral challenge and virus titers were determined. e Influenza-specific IgG antibodies were measured by ELISA using sera collected on the day of virus challenge. $f$ IFN- $\gamma$-secreting T cells were estimated by enzyme-linked immunospot assay, using splenocytes harvested on the day of virus challenge. Data are presented as mean \pm standard error of mean. ${ }^{* * *} p<0.001,{ }^{*} p<0.05$.

(Figure continued on next page.)

\section{Viruses}

Influenza A/California/04/2009 (pandemic H1N1, pH1N1), influenza A/Puerto Rico/8/1934 (PR8), influenza A/aquatic bird/ Korea/CN2-MA/2009 (H5N2), and influenza A/Environment/ Korea/W149/2006 (H5N1) viruses were cultivated in the allantoic cavities of embryonated chicken eggs. Viruses were titrated by calculating the $50 \%$ egg infectious dose $\left(\mathrm{EID}_{50}\right)$ and stored at $-80^{\circ} \mathrm{C}$ until use.

\section{Animals and Experimental Schedule}

Seven-week-old, female C57BL/6 mice were kept in pathogenfree, biosafety level-2 or -3 facilities at Korea Research Institute of Bioscience and Biotechnology (KRIBB) or Chungbuk National 

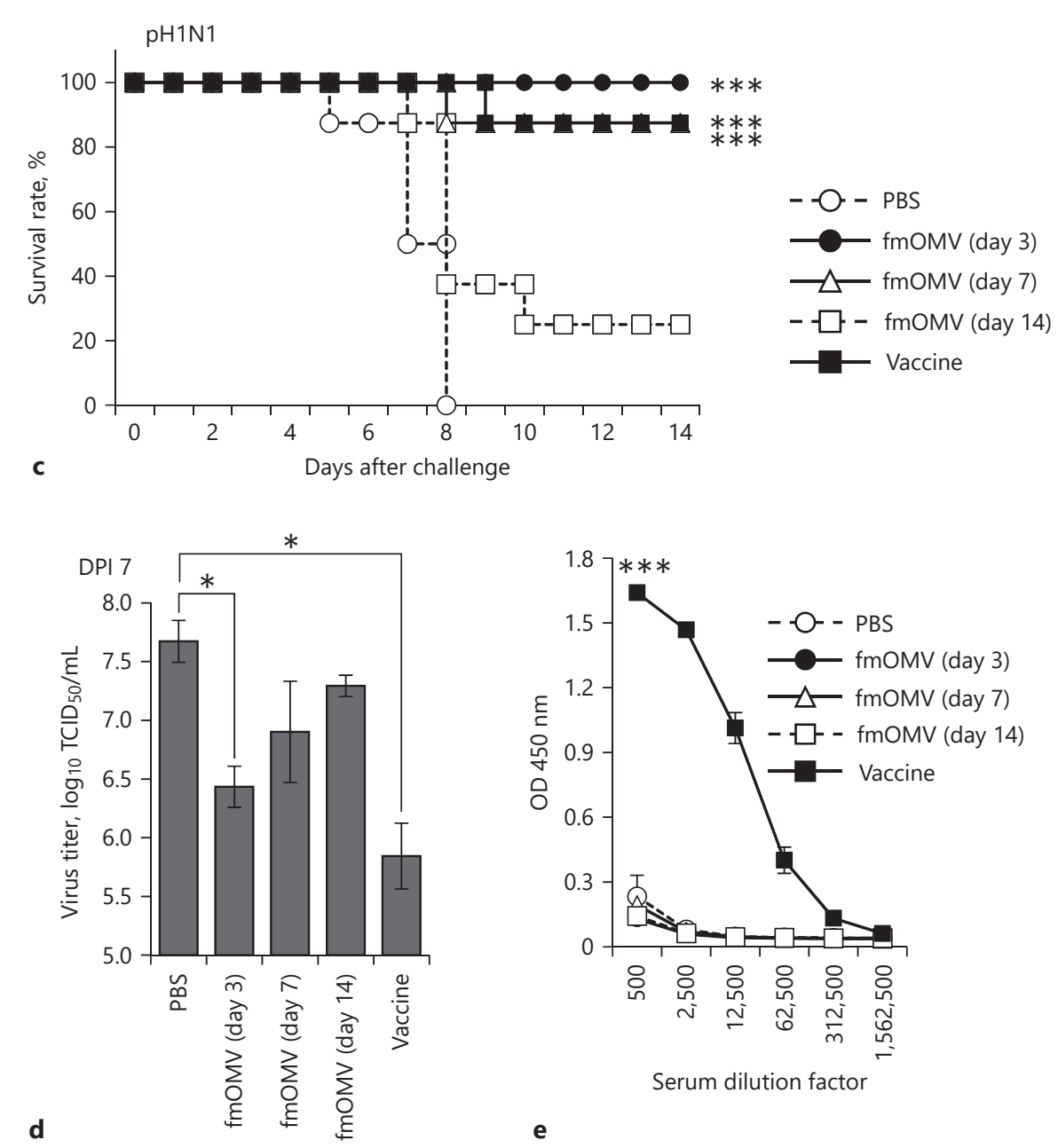

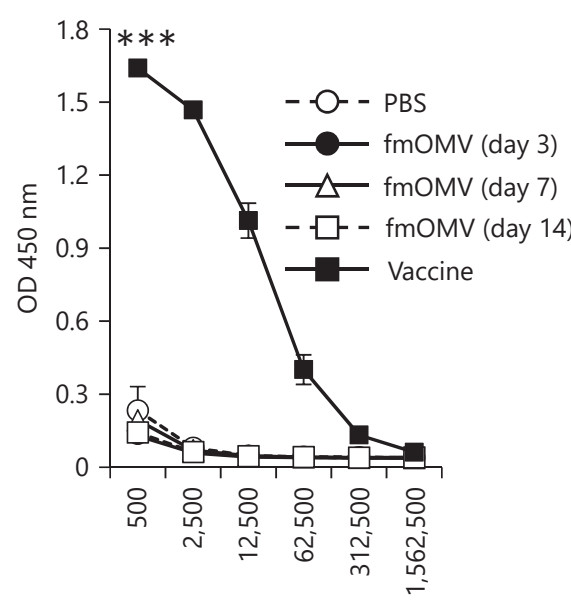

Serum dilution factor

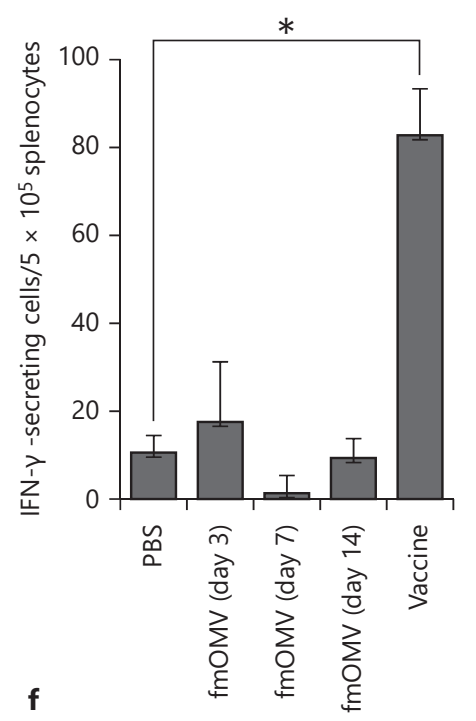

University, respectively. Mice were injected intranasally with fmOMV (10 $\mu \mathrm{g} /$ mouse) once. Three, 7 , or 14 days after fmOMV injection, mice were challenged with a 10 lethal dose $50\left(\mathrm{LD}_{50}\right)$ of $\mathrm{PR} 8, \mathrm{pH} 1 \mathrm{~N} 1, \mathrm{H} 5 \mathrm{~N} 2$, or highly pathogenic H5N1 viruses and their mortality rates were monitored for 2 weeks. The trivalent split influenza vaccine containing A/California/7/2009 (H1N1), A/Victo$\mathrm{ria} / 361 / 2011$ (H3N2), and B/Massachusetts/2/2012 (1.0 $\mu \mathrm{g}$ of HA/ mouse, Green Cross, Korea) was immunized either intranasally (Fig. 2) or intramuscularly (Fig. 5) twice at a 2-week interval. The vaccine-immunized groups were challenged 2 weeks after the booster injection. For intranasal injection, the total volume was adjusted to $30 \mu \mathrm{L} /$ mouse by using phosphate-buffered saline (PBS). A humane endpoint of $25 \%$ weight loss was used for this challenge study.

\section{Enzyme-Linked Immunosorbent Assay}

ELISA plates (ThermoFisher Scientific, MA, USA) were coated with vaccine antigen (200 ng/well), and then incubated with the serum samples. Bound antibodies were detected by sequential incubation with peroxidase goat anti-mouse total IgG (Cell Signaling
Technology, MA, USA) and 3,3',5, ' $^{\prime}$-tetramethylbenzidine substrate (BD Bioscience, CA, USA). Optical density was measured at $450 \mathrm{~nm}$ wavelength using VICTOR3 ${ }^{\mathrm{TM}}$ (PerkinElmer, MA, USA).

\section{Enzyme-Linked Immunospot (ELISPOT) Assay}

Influenza-specific IFN- $\gamma$-producing cells were quantified using a mouse IFN- $\gamma$ enzyme-linked immunospot set (BD Biosciences) on the day of virus challenge. Briefly, splenocytes $\left(5 \times 10^{5}\right.$ cells/ well) were incubated with inactivated $\mathrm{pH} 1 \mathrm{~N} 1$ virus on ELISPOT plates coated with IFN- $\gamma$ capture antibody. After 40 -h incubation, the plates were further incubated with biotinylated IFN- $\gamma$ detection antibody and then horseradish peroxidase-conjugated streptavidin. Spots were visualized by adding 3-amino-9-ethyl-carbazole substrate solution and counted using the BioSpot analyzer (Cellular Technology, OH, USA).

\section{Virus Titration}

Total lung homogenate samples were obtained at indicated time points, and then added to Madin-Darby canine kidney cells 


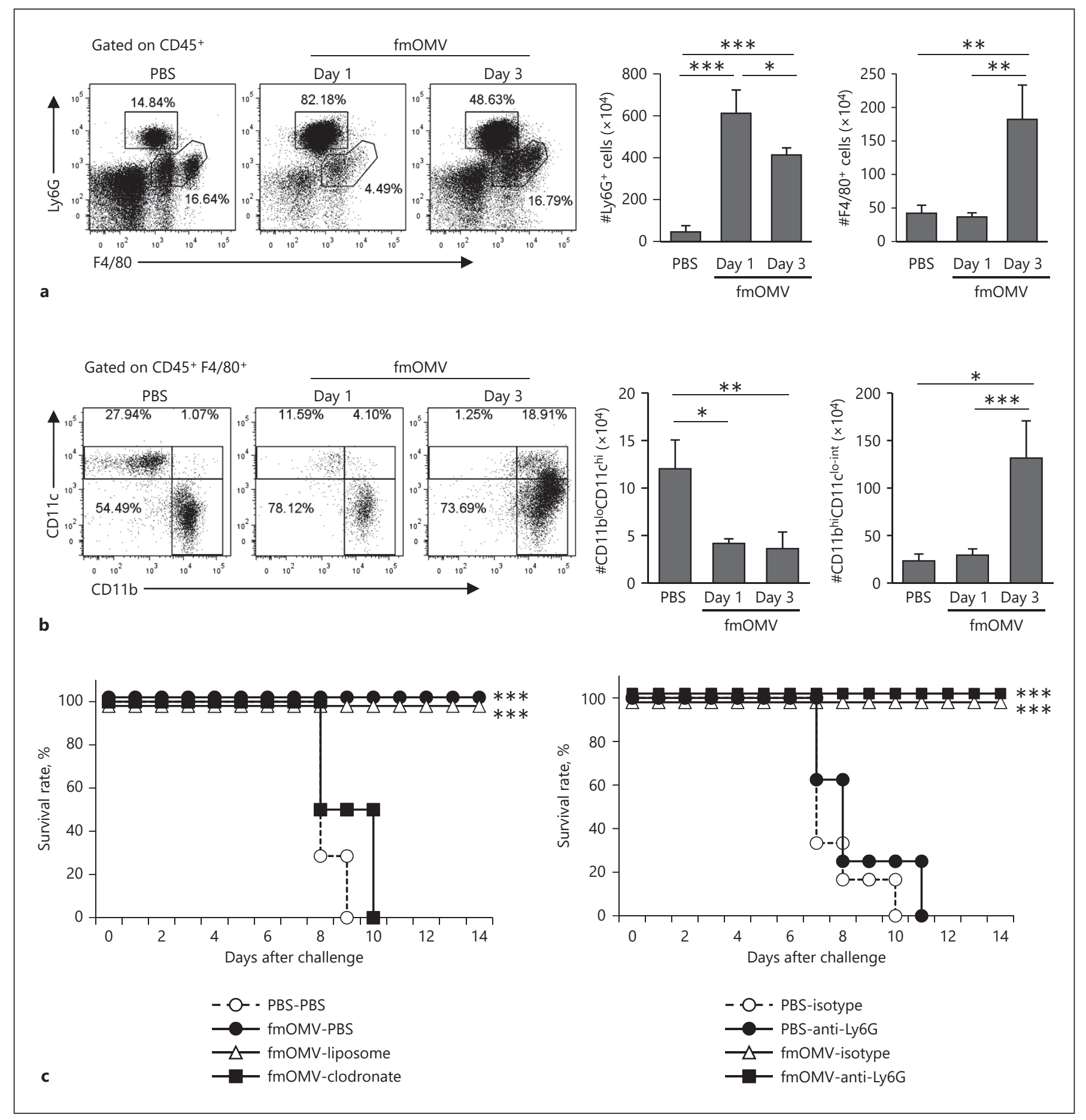

Fig. 3. Macrophages but not neutrophils are associated with antiinfluenza effect by fmOMV. a Macrophages and neutrophils were measured by fluorescence-activated cell sorting analysis of lung tissue at 1 and 3 days after fmOMV injection. $\mathbf{b}$ The $\mathrm{CD} 45^{+} \mathrm{F} 4 / 80^{+}$ macrophage population was subdivided in terms of CD11b and CD11c expression. c The survival rate of macrophage- or neutro- phil-depleted mice infected with $\mathrm{pH} 1 \mathrm{~N} 1$. After mice were injected with clodronate-liposome or anti-Ly6G, they were injected with fmOMV intranasally and infected with $10 \mathrm{LD}_{50}$ of $\mathrm{pH} 1 \mathrm{~N} 1$ at 3 days after fmOMV injection. Data are presented as mean \pm SEM and representative of at least three independent experiments. ${ }^{* * *} p<$ $0.001,{ }^{* *} p<0.01,{ }^{*} p<0.05$. 
with 10 -fold serial dilution. Three days after infection, virus titer was determined with a hemagglutinin test and calculated by the method of Reed and Muench, as previously described [24]. Virus titer was expressed as $\log _{10}$ of the $50 \%$ tissue culture-infective dose $\left(\mathrm{TCID}_{50}\right)$ per milliliter.

\section{Fluorescent Labeling of fmOMV}

fmOMV was labeled with Alexa Fluor 488 fluorescent dye (Alexa488) according to the manufacturer's instructions (ThermoFisher Scientific). In brief, $1 \mathrm{M}$ sodium bicarbonate buffer was added to fmOMV diluted in PBS, and then Alexa488 tetrafluorophenyl ester was added to the mixture. After incubation for $15 \mathrm{~min}$ at room temperature, unreacted dye was removed using a spin filter containing Bio-Gel P-6 fine resin.

\section{Flow Cytometry}

Samples were resuspended in fluorescence-activated cell sorting buffer (PBS containing 2.5\% FBS and $0.1 \%$ sodium azide) and incubated with Fc-block (anti-CD16/CD32; eBioscience, CA, USA). After washing, the cells were stained for CD11b, CD11c, SiglectF, CD40, CD45, CD80, CD86, MHC class II, F4/80, and Ly6G (eBioscience). Samples were acquired on Gallios ${ }^{\mathrm{TM}}$ (Beckman Coulter, CA, USA) and analyzed using FlowJo software (Tree Star, OH, USA).

\section{Depletion of Neutrophils and Macrophages}

Neutrophils were depleted by intraperitoneal injection of antimouse Ly6G antibody (500 $\mu \mathrm{g} /$ mouse, $1 \mathrm{~A} 8$ clone; Biolegend, CA, USA) $24 \mathrm{~h}$ before fmOMV treatment. For macrophage depletion, empty or clodronate-encapsulating liposomes (FormuMax, CA, USA) were administered via intravenous routes $(1.0 \mathrm{mg} / \mathrm{mouse})$ at 2 days before fmOMV administration.

\section{Quantitative RT-PCR}

RNA was isolated from the lung tissue using TRIzol (Invitrogen) and was reverse-transcribed with Moloney murine leukemia virus reverse transcriptase and oligo- $\mathrm{d}(\mathrm{T})$ according to the manufacturer's instructions. Quantitative RT-PCR was performed using specific primers (IFN- $\alpha$ : sense, $5^{\prime}$-ATGGCTAGGCTCTGTGCTTTCCT-3', antisense, 5'-AGGGCTCTC CAGACTTCTGCTCTG-3'; IFN- $\beta$ : sense, $5^{\prime}$-CCCTATGGAGATGACGGAGA-3', antisense, $5^{\prime}$-TCCCACGTCAATCTT TCCTC-3'; HPRT: sense, 5'-CAGACTGAAGAG CTACTGTAATGATCA-3' , antisense, $5^{\prime}$ TCA ACA ATCAAGACATTCTTTCCA- $3^{\prime}$ ) and SYBR Premix Ex Taq (Takara Bio) on a Dice TP800 Thermal Cycler (Takara Bio). The mRNA levels were normalized relative to the expression of Hprt mRNA.

\section{Multiplex Cytokine Immunoassay}

Bronchoalveolar lavage fluid (BALF) samples were harvested 3 days after fmOMV treatment. The cytokine levels were measured using a multiplex cytokine immunoassay system (Bio-Rad Laboratories, CA, USA) according to the manufacturer's instructions.

\section{Statistical Analysis}

Statistical differences among groups were assessed using a 2-tailed Student's $t$ test or a log-rank test with GraphPad Prism software. $p$ values of $<0.05$ were considered statistically significant.

\section{Results}

\section{fmOMV Stimulates Diverse TLRs}

Activation of various TLR signaling has been reported to initiate antiviral innate immunity [4]. Based on the fact that OMVs contain diverse bacterial components which can stimulate TLRs $[23,25,26]$, we previously generated a modified OMV harboring less endotoxic LPS (fmOMV, Fig. 1a) and investigated its safety and adjuvant effect using an influenza vaccine model [21]. In this study, we tested whether fmOMV initiates TLR 2, 3, 4, 5, and 9 signaling simultaneously, using HEK-Blue cells expressing individual TLRs. Treatment with fmOMV induced TLR2, TLR3, TLR4, TLR5, and TLR9 signaling in a dose-dependent manner (Fig. 1b). These data suggest that fmOMV treatment elicits innate immunity required to generate antiviral host immunity via simultaneous triggering of various TLR signaling.

\section{Antiviral Activity of fmOMV Is Independent of the Adaptive Immune Response}

Previously, we reported that OMV injection with a vaccine antigen increases vaccine-induced antibody responses using ovalbumin and influenza vaccine antigens [21, 23]. Since rapid induction of protective immunity in particular is required for vaccines against highly transmissible infectious diseases such as influenza, we first tested whether fmOMV could induce protective efficacy of an influenza vaccine at early time points after the injection. When mice were challenged both 5 and 14 days after immunization, the mice coimmunized with fmOMV exhibited reduced body weight loss and an increased survival rate, which were significantly higher than those achieved by vaccination without fmOMV (Fig. 2a). Intriguingly, the antigen-specific antibody was not detected in sera 5 days after immunization (Fig. 2b). This discrepancy between the protection rate and antibody response at day 5 after vaccination led to the possibility that fmOMV induces a protective response before the vaccine-induced antibody response is generated. To verify this hypothesis, mice were inoculated intranasally with fmOMV alone and then challenged with $\mathrm{pH} 1 \mathrm{~N} 1$ influenza virus at 3, 7, or 14 days after fmOMV administration. All fmOMV-injected mice survived at 3 days after fmOMV injection (Fig. 2c); however, survival rates decreased with an increase in the interval between fmOMV injection and $\mathrm{pH} 1 \mathrm{~N} 1$ virus challenge (day 7: 80\%, day 14:20\%). Additionally, the viral titer in the lungs was the lowest at 3 days after fmOMV injection (Fig. 2d). To investigate whether the protective effect of fmOMV was associated with adaptive immunity, 

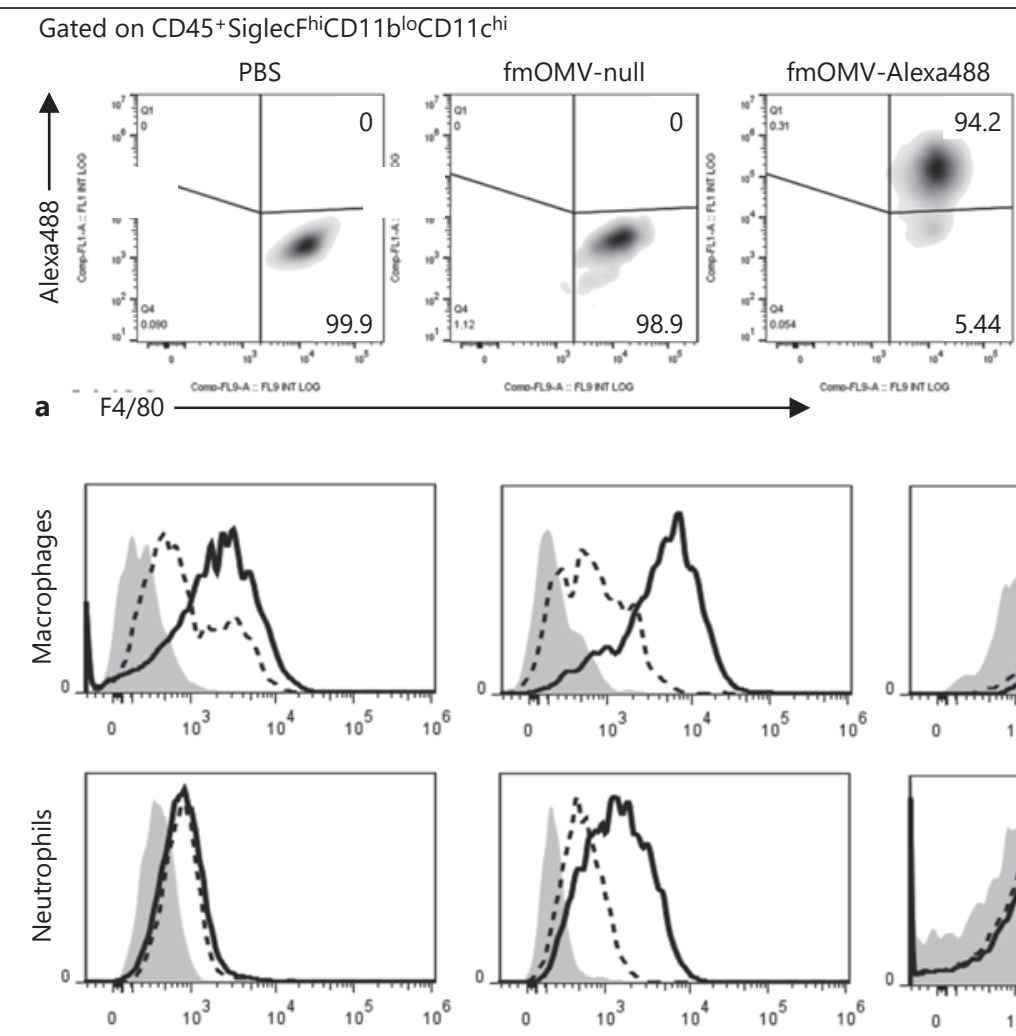

b

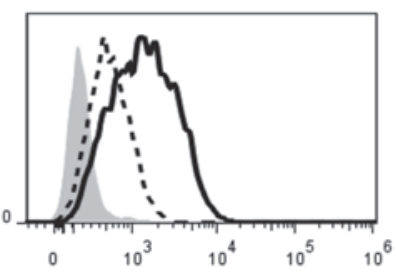

CD80
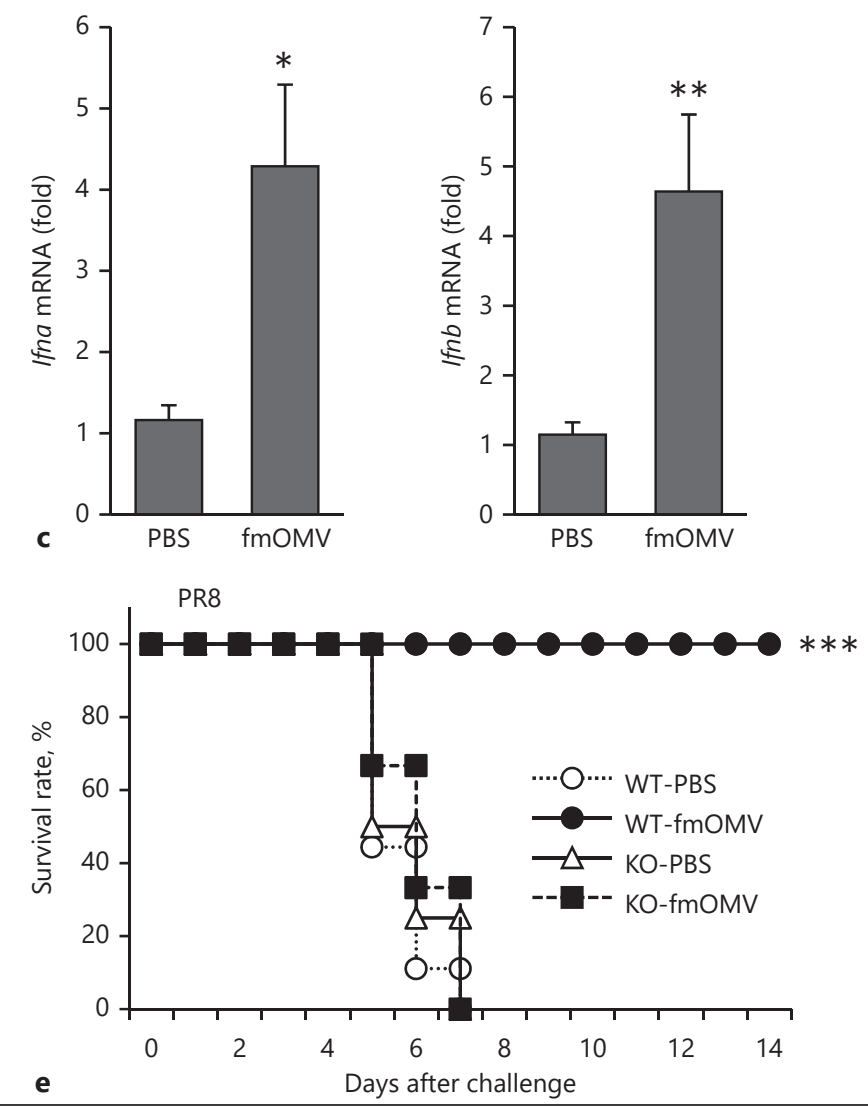

Isotype

- - - - PBS

fmOMV
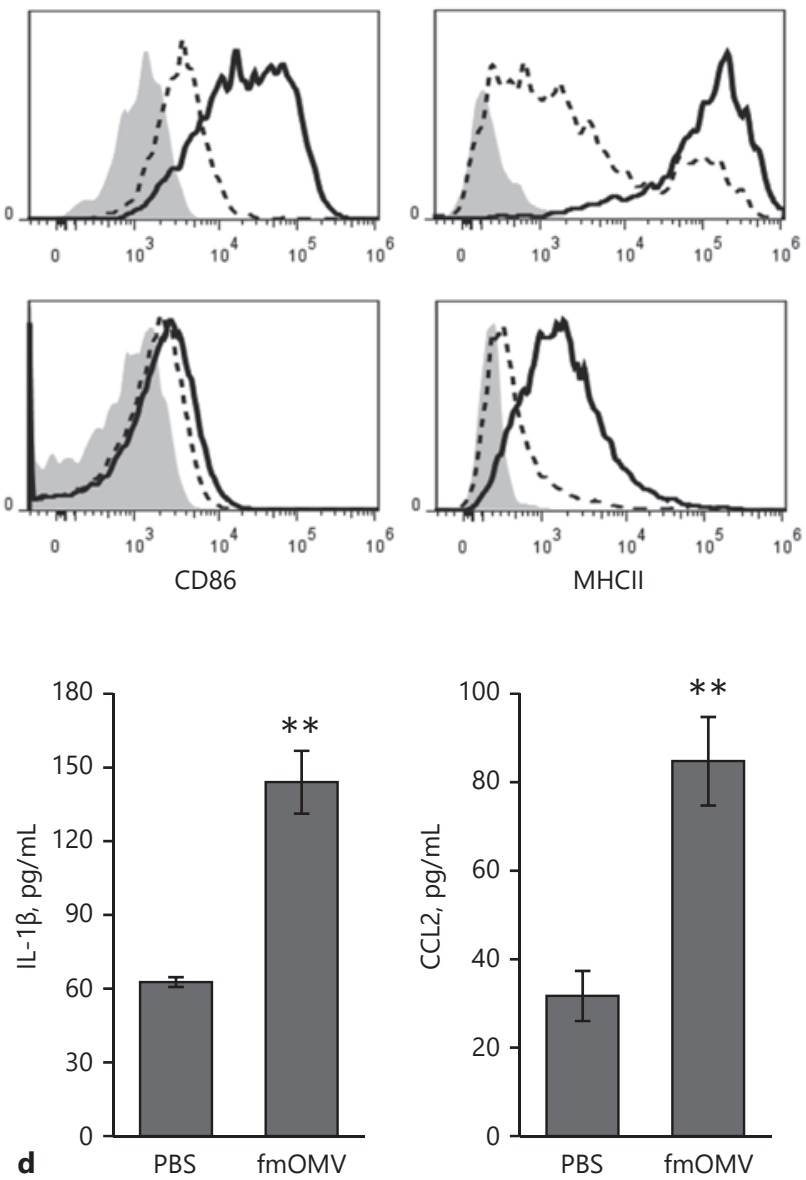

(For legend see next page.)

OMV-Mediated Antiviral Effect via Macrophages
J Innate Immun 2019;11:316-329 DOI: $10.1159 / 000494098$ 
we measured antigen-specific antibody and $\mathrm{T}$ cell responses on the day of virus challenge. As expected, neither the antibody response nor theinterferon (IFN)- $\gamma$-secreting $\mathrm{T}$ cell response specific for the vaccine were detected at 3 , 7, or 14 days after fmOMV injection (Fig. 2e, f), indicating that the fmOMV-induced antiviral effect is not associated with adaptive immunity.

\section{Macrophages but Not Neutrophils Are Associated with} Anti-Influenza Effect by fmOMV

Given that the fmOMV-induced antiviral effect was independent of adaptive immunity, we hypothesized that the antiviral activity is associated with innate immunity. Since previous reports showed that macrophages and neutrophils comprise the majority of innate immune cells responsible for the antiviral response in an influenza infection model [27], we measured the change in counts of macrophages and neutrophils in the lungs after fmOMV injection. Both cell counts significantly increased after fmOMV injection (Fig. 3a). Additional analysis of the change in macrophage phenotypes showed that major population of $\mathrm{F} 4 / 80^{+}$cells in the lungs was $\mathrm{CD} 11 \mathrm{~b}^{\mathrm{hi}} \mathrm{CD}$ $11 c^{\text {lo-int }}$ (Fig. 3b) [28].

To identify which innate immune cells mainly contributed to the antiviral activity by fmOMV, we monitored the survival rate of fmOMV-injected mice under neutrophil- or macrophage-depleted conditions. Depletion of macrophages by clodronate-liposome injection completely abrogated the antiviral effect by fmOMV administration (Fig. 3c), indicating that macrophages play an important role in the antiviral effect by fmOMV against influenza virus infection (Fig. 3c, left). After neutrophil depletion by anti-Ly6G antibody injection, the antiviral

Fig. 4. fmOMV activates macrophages and induces antiviral cytokines in the lung tissue. a Mice were intranasally administered with $10 \mu \mathrm{g}$ of Alexa Fluor 488 (Alexa488)-labeled fmOMV. After $3 \mathrm{~h}$, the population of Alexa488 and F4/80-positive cells were determined by flow cytometry, gated on $\mathrm{CD} 45^{+}$Siglec $\mathrm{F}^{\mathrm{hi}} \mathrm{CD} 11 \mathrm{~b}^{\mathrm{lo}} \mathrm{CD} 11 \mathrm{c}^{\text {hi }}$ bronchoalveolar lavage cells. $\mathbf{b}$ The expression of activation markers on macrophages (upper panels) and neutrophils (lower panels) in the lungs were analyzed at 3 days after fmOMV injection. c, $\mathbf{d}$ The levels of type I interferons, IL- $1 \beta$, and C-C motif chemokine ligand 2 (CCL2) in the lungs were determined by RT-PCR and multiplex cytokine immunoassay, respectively. e Type I IFN receptor 1 knockout (IFNAR1KO) mice ( $n=4$ or 6 ) were injected with fmOMV. Three days after the injection, the mice were infected with PR8 virus, and the survival rates were monitored for 2 weeks after the viral challenge. Data are presented as mean \pm SEM and representative of at least three independent experiments. *** $p<0.001,{ }^{* *} p<0.01, * p<0.05$. effect by fmOMV was not affected, showing that neutrophils are not associated with antiviral effect by fmOMV (Fig. 3c, right). These data suggest that the antiviral effect by fmOMV injection is associated with an increase in macrophages in the lungs.

\section{fmOMV Activates Macrophages and Induces Antiviral} Cytokines in the Lung Tissue

It has been known that alveolar macrophages (AMs) are the major population that firstly recognizes foreign materials and induces subsequent immune activation in the lungs. To investigate whether fmOMV-induced antiviral effect was mediated by direct interaction of fmOMV with AMs, we injected Alexa488-labelled fmOMV (fmOMV-Alexa488) and quantified the fluorescence signal in AMs. At $3 \mathrm{~h}$ after fmOMV-Alexa488 injection, 94.2\% of $\mathrm{CD}_{4} 5^{+}$SiglecF ${ }^{\text {hi }} \mathrm{CD} 11 \mathrm{~b}^{\text {lo }} \mathrm{CD} 11 \mathrm{c}^{\mathrm{hi}} \mathrm{F} 4 / 80^{+}$cells were Alexa488-positive (Fig. 4a), showing direct interaction of fmOMV with AMs.

Upon activation, AMs secrete proinflammatory chemokines which in turn lead to recruitment of diverse immune cells ([29]), as shown in Figure 3a, b. Given that macrophages are indispensable for the fmOMV-mediated antiviral effect (Fig. 3c, left), we next investigated the characteristics of infiltrated macrophages in lung tissue 3 days after fmOMV injection. The activation markers, such as CD40, CD80, CD86, and MHC class II on macrophages, were upregulated after fmOMV injection (Fig. 4b). We also analyzed the levels of antiviral cytokines and chemokines after fmOMV injection. The level of IFN- $\alpha$ and $\beta$, IL- $1 \beta$, and C-C motif chemokine ligand 2 (CCL2, MCP-1) in the lung tissue was increased by fmOMV injection (Fig. 4c, d), indicating that fmOMV activated the innate immune system leading to antiviral soluble factors. Given that fmOMV induces significant production of type I IFNs, we further investigated whether type I IFNs contributed to fmOMV-mediated protection using mice lacking a type I IFN receptor (IFNAR$1 \mathrm{KO}$ ). When IFNAR1 KO mice were treated with fmOMV and then challenged with a lethal dose of PR8 virus, all mice lost weight and eventually died (Fig. 4e), indicating that type I IFNs play an important role in the fmOMVmediated antiviral effect.

\section{fmOMV Provide Broad and Potent Protection against Diverse Influenza A Viruses}

To further examine whether fmOMV protects against a broad spectrum of influenza virus subtypes, we additionally challenged fmOMV-injected mice with PR8, $\mathrm{H} 5 \mathrm{~N} 2$, and highly pathogenic H5N1 viruses. Eighty to 

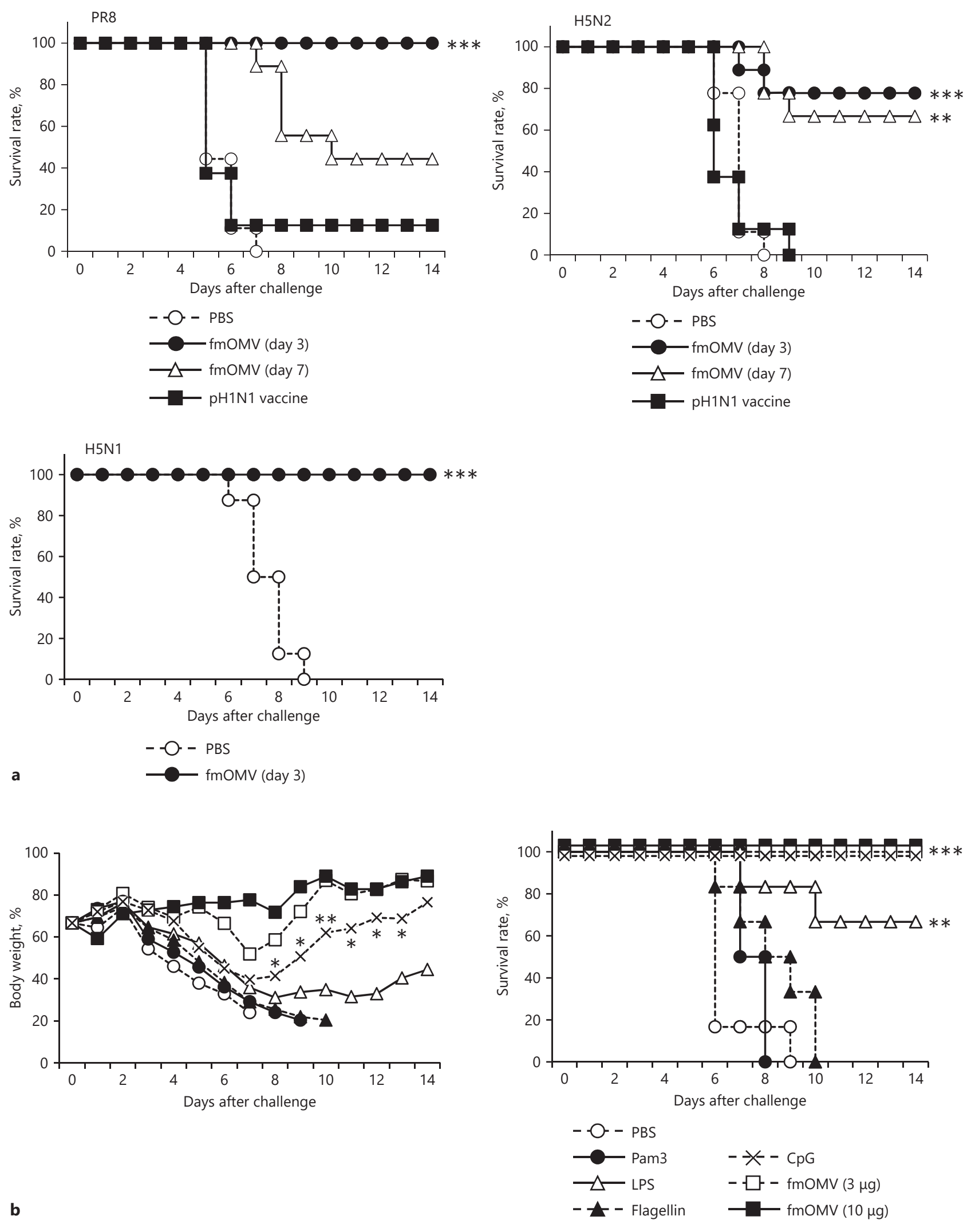

5

b

(For legend see next page.)

OMV-Mediated Antiviral Effect via 
one hundred percent of the fmOMV-injected mice survived the $\mathrm{PR} 8, \mathrm{H} 5 \mathrm{~N} 2$, and $\mathrm{H} 5 \mathrm{~N} 1$ viral challenge at 3 days after fmOMV injection (Fig. 5a). The protective effect of fmOMV was compared with other TLR ligands: Pam3, LPS, flagellin, and CpG, which have been reported to protect against influenza viruses $[11,12,30]$. Interestingly, while the TLR ligands except $\mathrm{CpG}$ were ineffective, fmOMV ( 3 and $10 \mu \mathrm{g}$ ) completely protected against lethal influenza virus challenge (Fig. 5b). Although CpG completely protected the viral challenge in terms of the survival rate (Fig. 5b, right), the body weight of mice administered $\mathrm{CpG}$ significantly declined upon viral challenge compared to that of mice administered fmOMV (Fig. 5b, left). Consistent with a previous report [21], the mobility, food intake, and body weight of the mice were normal, and inflammation in the lung tissue was not observed when fmOMV was intranasally injected (data not shown). These data indicate that fmOMV provide broad and potent protection against diverse influenza $\mathrm{A}$ viruses (IAVs) without endotoxic inflammation.

\section{Discussion}

Emerging infectious diseases caused by yet unidentified viruses or new variants of known viruses are a constant threat to human health, as exemplified by Middle East respiratory syndrome coronavirus and influenza viruses. These pandemic or epidemic outbreaks necessitate the availability of therapeutics and vaccines. However, factors such as lack of information regarding the virus and the time-consuming developmental process have resulted in an urgent need for an effective antiviral agent that protects against a broad spectrum of viruses immediately. In this study, we demonstrated that intranasal injection of fmOMV not only protects against infection by a broad spectrum of influenza viral strains, but also elicits

Fig. 5. fmOMV provide broad and potent protection against diverse influenza A viruses. a Mice $(n=8-9)$ were injected with fmOMV and challenged with $10 \mathrm{LD}_{50}$ of PR8, H5N2, and highly pathogenic $\mathrm{H} 5 \mathrm{~N} 1$ influenza viruses at the indicated time points. The vaccinated group was immunized intramuscularly with the trivalent split influenza vaccine containing $\mathrm{pH} 1 \mathrm{~N} 1$ antigen twice at a 2 -week interval $(n=8)$. Two weeks after the second injection, the mice were challenged with each virus. b Mice $(n=8)$ were intranasally injected with each indicated TLR ligand $(3 \mu \mathrm{g})$ and challenged with $10 \mathrm{LD}_{50}$ of the $\mathrm{pH} 1 \mathrm{~N} 1$ virus. $\mathbf{a}$, b The survival rates were monitored for 2 weeks after the viral challenge. These data are representative of two or three independent experiments. ${ }^{* * *} p<0.001,{ }^{* *} p<0.01,{ }^{*} p<0.05$. this antiviral effect as early as 3 days after administration. Cell depletion and subtype analysis studies revealed that an increase and activation of macrophages by fmOMV injection provided broad-spectrum antiviral effects.

Previous reports showed that AMs play an indispensable role in the protection against airway infection with influenza viruses [31-34]. Upon infection with influenza viruses, AMs primarily produce type I IFNs that play an important role in the protection against influenza viruses by both inhibiting viral replication and suppressing excessive tissue inflammation $[35,36]$. In this study, we observed activation of TLR3 and 4, which are known to induce type I IFNs via interferon regulatory factor 3 , in vitro (Fig. 1b), and significant increase in type I IFNs in vivo after fmOMV treatment (Fig. 4c). In addition to LPS, OMVs contain bacteria-derived RNA molecules and activate TLR3, which coincides well with our observation $[25,37]$. It is possible that type I IFNs induced by fmOMV promote antiviral molecular milieu in lung epithelial cells, and these "pre-armed" epithelial cells effectively suppressed influenza virus replication regardless of the evading mechanism of influenza virus in this study.

We observed that $\mathrm{F} 4 / 80^{+} \mathrm{CD} 11 \mathrm{~b}^{\mathrm{hi}} \mathrm{CD} 11 \mathrm{c}^{\mathrm{lo}-\text { int }}$ cells massively infiltrated into the lungs 3 days after fmOMV injection (Fig. 3b) and that these macrophages are indispensable for the antiviral effect of fmOMV (Fig. 3c, left). When AMs are activated, they produce CCL2, resulting in the recruitment of bone marrow-derived macrophages to the lungs [29]. In this study, we showed that fmOMV increased the level of CCL2 in BALF (Fig. 4d, right), suggesting that massive infiltration of macrophages was induced by AM-derived chemokines. Inflammatory macrophages suppress viral replication after influenza virus infection [38]. In particular, stimulation of various TLRs using LPS, imiquimod, peptidoglycan, or $\beta$-glucan is known to transform macrophages to a state called "trained immunity" that is hyperresponsive to pathogenic re-infection $[8,39]$. Specifically, TLR stimulation induces a decrease in repressive histone $\mathrm{H} 3 \mathrm{~K} 9 \mathrm{me} 2$ marks via phosphorylation of ATF7. This epigenetic change causes an increase in basal expression of genes required for protection against pathogens by macrophages. Considering that fmOMV can stimulate various TLRs (Fig. 1b), fmOMV injection may transform recruited macrophages to the hyperresponsive state presumably via epigenetic changes.

Injection of fmOMV induced IL- $1 \beta$ secretion in the lung tissue (Fig. $4 \mathrm{~d}$, left). In contrast to the case that LPS or flagellin located outside of the cells can only activate corresponding TLRs, the ligands introduced into the intracellular compartment activate NLRP3 and the NL- 
RC4-dependent inflammasome, respectively [40, 41]. Detection of IL- $1 \beta$ in BALF indicates that fmOMV enters the target cells, leading to a sequential activation of the inflammasome and proteolytic cleavage of IL- $1 \beta$ precursor [42]. Consistent with our interpretation, it was recently reported that OMVs mediate cytosolic localization of LPS and activate caspase-11 [43].

Neutrophils have a protective role in influenza virus infection [44, 45]. In this study, however, depletion of neutrophils did not decrease survival rate in fmOMV-injected and influenza-challenged mice, suggesting that neutrophils did not participate in antiviral activities provided by fmOMV in our experimental model (Fig. 3c, right). Antiviral activities of neutrophils are mainly associated with secretion of antiviral molecules such as longchain pentraxin (PTX3), defensin, and formation of neutrophil extracellular traps after influenza virus infection [46-48]. These molecules are secreted from neutrophils after activation via interaction directly with influenza virus or virus-induced molecular inflammatory milieu. It is speculated that in fmOMV-injected mice, infiltrated macrophages have sufficiently suppressed disease severity after influenza virus infection. Therefore, viral load and inflammatory cytokines may have been insufficient to activate neutrophils to produce antiviral molecules after influenza virus infection in fmOMV-injected mice. Meanwhile, neutrophil activation is known to intensify disease severity during influenza infection [49]; however, this was not observed in the present study, in terms of change in body weight and survival rates of fmOMV-injected mice (Fig. 2c, 3c, and 5a). This suggests that there was nil or relatively low activation of neutrophils upon influenza virus infection in fmOMV-injected mice, coinciding well with our observation (Fig. 3c, right).

In our study, fmOMV pretreatment successfully protected the mice against diverse IAVs; PR8, pH1N1, H5N2, and highly pathogenic H5N1 (Fig. 2a and 5a). It has been reported that pretreatment with a single TLR ligand provided differential protective efficacy depending on the challenging influenza subtypes or strains $[9,11,14,30]$. TLR4 activation alone was sufficient to protect $\mathrm{H} 5$ subtype, whereas simultaneous activation of TLR 2 and 4 was required for the protection against PR8 (H1) subtype [11]. Pam2Cys, a TLR2 ligand, has been reported to elicit $80 \%$ survival rate after PR8 virus infection $[9,30]$. In addition, costimulation of TLR2 and TLR9 protects the host against $\mathrm{H} 3 \mathrm{~N} 2$ virus infection completely, but the effect was reduced up to $50 \%$ in an $\mathrm{H} 1 \mathrm{~N} 1$ virus infection model [12]. Since fmOMV used in this study is a complex of various TLR ligands and presumably capable of simulta- neously activating TLRs and cytosolic pattern recognition receptors, it is probable that fmOMV leads to the higher protective efficacy against diverse IAVs. Further investigation is necessary to determine the underlying mechanisms for differential protective efficacy of each TLR signal against different virus strains.

In conclusion, we showed that fmOMV injection protected against infection by a wide spectrum of IAV strains and this antiviral effect was mediated by infiltrated macrophages. Our findings show potential for development of an efficient and broad-spectrum antiviral agent against influenza as well as emerging infectious diseases.

\section{Statement of Ethics}

All animal experiments were approved by the Institutional Animal Use and Care Committee of KRIBB and performed in accordance with the Guide for the Care and Use of Laboratory Animals published by the US National Institutes of Health.

\section{Disclosure Statement}

The authors declare that they have no competing interests.

\section{Funding Sources}

This work was supported by a grant of the Bio \& Medical Technology Development Program of the National Research Foundation of Korea (NRF) funded by the Ministry of Science \& ICT (2016M3A9B6918675) and the KRIBB Initiative programs (KGM4691713 and KGM9411711). This research was also supported by Basic Research Program of the NRF funded by the Ministry of Science \& ICT (2017R1C1B1005137). Work in S.-H. Kim's laboratory was supported by Korea Institute of Planning and Evaluation for Technology in Food, Agriculture, Forestry and Fisheries (IPET) through Agriculture, Food and Rural Affairs Research Center Support Program, funded by Ministry of Agriculture, Food and Rural Affairs (MAFRA) (716002-7).

\section{References}

1 Thompson WW, Shay DK, Weintraub E, Brammer L, Bridges CB, Cox NJ, et al. Influenza-associated hospitalizations in the United States. JAMA. 2004 Sep;292(11):1333-40.

2 Martcheva M. An evolutionary model of influenza A with drift and shift. J Biol Dyn. 2012;6(2):299-332.

3 Russell CA, Fonville JM, Brown AE, Burke DF, Smith DL, James SL, et al. The potential for respiratory droplet-transmissible A/ $\mathrm{H} 5 \mathrm{~N} 1$ influenza virus to evolve in a mammalian host. Science. 2012 Jun;336(6088):15417. 
4 Lester SN, Li K. Toll-like receptors in antiviral innate immunity. J Mol Biol. 2014 Mar; 426(6):1246-64.

5 Ellis TN, Leiman SA, Kuehn MJ. Naturally produced outer membrane vesicles from Pseudomonas aeruginosa elicit a potent innate immune response via combined sensing of both lipopolysaccharide and protein components. Infect Immun. 2010 Sep;78(9): 3822-31.

6 Pore D, Mahata N, Chakrabarti MK. Outer membrane protein A (OmpA) of Shigella flexneri 2a links innate and adaptive immunity in a TLR2-dependent manner and involvement of IL-12 and nitric oxide. J Biol Chem. 2012 Apr;287(15):12589-601.

7 Kleinnijenhuis J, Quintin J, Preijers F, Joosten LA, Ifrim DC, Saeed S, et al. Bacille CalmetteGuerin induces NOD2-dependent nonspecific protection from reinfection via epigenetic reprogramming of monocytes. Proc Natl Acad Sci USA. 2012 Oct;109(43):17537-42.

8 Yoshida K, Maekawa T, Zhu Y, Renard-Guillet $\mathrm{C}$, Chatton B, Inoue K, et al. The transcription factor ATF7 mediates lipopolysaccharide-induced epigenetic changes in macrophages involved in innate immunological memory. Nat Immunol. 2015 Oct;16(10): 1034-43.

9 Abdul-Careem MF, Firoz Mian M, Gillgrass AE, Chenoweth MJ, Barra NG, Chan T, et al. FimH, a TLR4 ligand, induces innate antiviral responses in the lung leading to protection against lethal influenza infection in mice. Antiviral Res. 2011 Nov;92(2):346-55.

10 Kawai T, Akira S. The role of pattern-recognition receptors in innate immunity: update on Toll-like receptors. Nat Immunol. 2010 May;11(5):373-84.

11 Shinya K, Okamura T, Sueta S, Kasai N, Tanaka M, Ginting TE, et al. Toll-like receptor prestimulation protects mice against lethal infection with highly pathogenic influenza viruses. Virol J. 2011 Mar;8(1):97.

12 Tuvim MJ, Gilbert BE, Dickey BF, Evans SE. Synergistic TLR2/6 and TLR9 activation protects mice against lethal influenza pneumonia. PLoS One. 2012;7(1):e30596.

13 Wong JP, Christopher ME, Salazar AM, Dale RM, Sun LQ, Wang M. Nucleic acid-based antiviral drugs against seasonal and avian influenza viruses. Vaccine. 2007 Apr;25(16): 3175-8.

14 Wong JP, Christopher ME, Viswanathan S, Dai X, Salazar AM, Sun LQ, et al. Antiviral role of toll-like receptor-3 agonists against seasonal and avian influenza viruses. Curr Pharm Des. 2009;15(11):1269-74.

15 Shinya K, Ito M, Makino A, Tanaka M, Miyake K, Eisfeld AJ, et al. The TLR4-TRIF pathway protects against $\mathrm{H} 5 \mathrm{~N} 1$ influenza virus infection. J Virol. 2012 Jan;86(1):19-24.

16 Kuehn MJ, Kesty NC. Bacterial outer membrane vesicles and the host-pathogen interaction. Genes Dev. 2005 Nov;19(22):2645-55.
17 Roy N, Barman S, Ghosh A, Pal A, Chakraborty $\mathrm{K}$, Das SS, et al. Immunogenicity and protective efficacy of Vibrio cholerae outer membrane vesicles in rabbit model. FEMS Immunol Med Microbiol. 2010 Oct;60(1):18-27.

18 Shang ES, Champion CI, Wu XY, Skare JT, Blanco DR, Miller JN, et al. Comparison of protection in rabbits against host-adapted and cultivated Borrelia burgdorferi following infection-derived immunity or immunization with outer membrane vesicles or outer surface protein A. Infect Immun. $2000 \mathrm{Jul} ; 68(7)$ : 4189-99.

19 Holst J, Martin D, Arnold R, Huergo CC, Oster P, O'Hallahan J, et al. Properties and clinical performance of vaccines containing outer membrane vesicles from Neisseria meningitidis. Vaccine. 2009 Jun;27 Suppl 2:B3-12.

20 Nevot M, Deroncelé V, Messner P, Guinea J, Mercadé E. Characterization of outer membrane vesicles released by the psychrotolerant bacterium Pseudoalteromonas antarctica NF3. Environ Microbiol. 2006 Sep;8(9):1523-33.

21 Lee TY, Kim CU, Bae EH, Seo SH, Jeong DG Yoon SW, et al. Outer membrane vesicles harboring modified lipid A moiety augment the efficacy of an influenza vaccine exhibiting reduced endotoxicity in a mouse model. Vaccine. 2017 Jan;35(4):586-95.

22 Shim SM, Song EJ, Song D, Lee TY, Kim DJ, $\mathrm{Nam} \mathrm{JH}$, et al. Nontoxic outer membrane vesicles efficiently increase the efficacy of an influenza vaccine in mice and ferrets. Vaccine. 2017 Jun;35(30):3741-8.

23 Lee DH, Kim SH, Kang W, Choi YS, Lee SH, Lee SR, et al. Adjuvant effect of bacterial outer membrane vesicles with penta-acylated lipopolysaccharide on antigen-specific $\mathrm{T}$ cell priming. Vaccine. 2011 Oct;29(46):8293-301.

24 Kim EH, Lee JH, Pascua PN, Song MS, Baek $\mathrm{YH}$, Kwon HI, et al. Prokaryote-expressed M2e protein improves H9N2 influenza vaccine efficacy and protection against lethal influenza A virus in mice. Virol J. 2013 Apr; 10(1):104

25 Fransen F, Boog CJ, van Putten JP, van der Ley P. Agonists of Toll-like receptors 3, 4, 7, and 9 are candidates for use as adjuvants in an outer membrane vaccine against Neisseria meningitidis serogroup B. Infect Immun. 2007 Dec;75(12):5939-46.

26 Fransen F, Stenger RM, Poelen MC, van Dijken HH, Kuipers B, Boog CJ, et al. Differential effect of TLR2 and TLR4 on the immune response after immunization with a vaccine against Neisseria meningitidis or Bordetella pertussis. PLoS One. 2010 Dec;5(12):e15692.

27 Tripathi S, White MR, Hartshorn KL. The amazing innate immune response to influenza A virus infection. Innate Immun. 2015 Jan; 21(1):73-98.

28 Lee HS, Kwon HS, Park DE, Woo YD, Kim HY, Kim HR, et al. Thalidomide inhibits alternative activation of macrophages in vivo and in vitro: a potential mechanism of antiasthmatic effect of thalidomide. PLoS One. 2015 Apr;10(4):e0123094.
29 Janssen WJ, Barthel L, Muldrow A, OberleyDeegan RE, Kearns MT, Jakubzick C, et al. Fas determines differential fates of resident and recruited macrophages during resolution of acute lung injury. Am J Respir Crit Care Med. 2011 Sep; 184(5):547-60.

30 Tan AC, Mifsud EJ, Zeng W, Edenborough K, McVernon J, Brown LE, et al. Intranasal administration of the TLR2 agonist Pam2Cys provides rapid protection against influenza in mice. Mol Pharm. 2012 Sep;9(9):2710-8.

31 Schneider C, Nobs SP, Heer AK, Kurrer M, Klinke G, van Rooijen N, et al. Alveolar macrophages are essential for protection from respiratory failure and associated morbidity following influenza virus infection. PLoS Pathog. 2014 Apr;10(4):e1004053.

32 Tumpey TM, García-Sastre A, Taubenberger JK, Palese P, Swayne DE, Pantin-Jackwood $M J$, et al. Pathogenicity of influenza viruses with genes from the 1918 pandemic virus: functional roles of alveolar macrophages and neutrophils in limiting virus replication and mortality in mice. J Virol. 2005 Dec;79(23): 14933-44.

33 Kim HM, Lee YW, Lee KJ, Kim HS, Cho SW, van Rooijen N, et al. Alveolar macrophages are indispensable for controlling influenza viruses in lungs of pigs. J Virol. 2008 May;82(9): 4265-74.

34 Tate MD, Pickett DL, van Rooijen N, Brooks AG, Reading PC. Critical role of airway macrophages in modulating disease severity during influenza virus infection of mice. J Virol. 2010 Aug;84(15):7569-80.

35 Arimori Y, Nakamura R, Yamada H, Shibata $\mathrm{K}$, Maeda N, Kase T, et al. Type I interferon limits influenza virus-induced acute lung injury by regulation of excessive inflammation in mice. Antiviral Res. 2013 Sep;99(3):230-7.

36 Kumagai Y, Takeuchi O, Kato H, Kumar H, Matsui K, Morii E, et al. Alveolar macrophages are the primary interferon-alpha producer in pulmonary infection with RNA viruses. Immunity. 2007 Aug;27(2):240-52.

37 Dorward DW, Garon CF, Judd RC. Export and intercellular transfer of DNA via membrane blebs of Neisseria gonorrhoeae. J Bacteriol. 1989 May;171(5):2499-505.

38 Londrigan SL, Short KR, Ma J, Gillespie L, Rockman SP, Brooks AG, et al. Infection of Mouse Macrophages by Seasonal Influenza Viruses Can Be Restricted at the Level of Virus Entry and at a Late Stage in the Virus Life Cycle. J Virol. 2015 Dec;89(24):12319-29.

39 Netea MG, Quintin J, van der Meer JW. Trained immunity: a memory for innate host defense. Cell Host Microbe. 2011 May;9(5): 355-61.

40 Zhao Y, Yang J, Shi J, Gong YN, Lu Q, Xu H, et al. The NLRC4 inflammasome receptors for bacterial flagellin and type III secretion apparatus. Nature. 2011 Sep;477(7366):596600

Bae/Seo/Kim/Jang/Song/Lee/Jeong/Lee/

Park/Lee/Kim/Kim/Kim 
41 Schmid-Burgk JL, Gaidt MM, Schmidt T, Ebert TS, Bartok E, Hornung V. Caspase-4 mediates non-canonical activation of the NLRP3 inflammasome in human myeloid cells. Eur J Immunol. 2015 Oct;45(10):2911-7.

42 Lopez-Castejon G, Brough D. Understanding the mechanism of IL-1 $\beta$ secretion. Cytokine Growth Factor Rev. 2011 Aug;22(4):189-95.

43 Vanaja SK, Russo AJ, Behl B, Banerjee I, Yankova M, Deshmukh SD, et al. Bacterial Outer Membrane Vesicles Mediate Cytosolic Localization of LPS and Caspase-11 Activation. Cell. 2016 May;165(5):1106-19.
44 Tate MD, Ioannidis LJ, Croker B, Brown LE, Brooks AG, Reading PC. The role of neutrophils during mild and severe influenza virus infections of mice. PLoS One. 2011 Mar; 6(3):e17618.

45 Tate MD, Deng YM, Jones JE, Anderson GP, Brooks AG, Reading PC. Neutrophils ameliorate lung injury and the development of severe disease during influenza infection. J Immunol. 2009 Dec;183(11):7441-50.

46 Hartshorn KL, White MR, Tecle T, Holmskov $\mathrm{U}$, Crouch EC. Innate defense against influenza A virus: activity of human neutrophil defensins and interactions of defensins with surfactant protein D. J Immunol. 2006 Jun; 176(11):6962-72.
47 Reading PC, Bozza S, Gilbertson B, Tate M, Moretti S, Job ER, et al. Antiviral activity of the long chain pentraxin PTX3 against influenza viruses. J Immunol. 2008 Mar; 180(5): 3391-8.

48 Tripathi S, Verma A, Kim EJ, White MR, Hartshorn KL. LL-37 modulates human neutrophil responses to influenza A virus. J Leukoc Biol. 2014 Nov;96(5):931-8.

49 Sakai S, Kawamata H, Mantani N, Kogure T, Shimada Y, Terasawa K, et al. Therapeutic effect of anti-macrophage inflammatory protein 2 antibody on influenza virus-induced pneumonia in mice. J Virol. 2000 Mar;74(5): $2472-6$ 